\title{
Correction to: miR168 targets Argonaute1A mediated miRNAs regulation pathways in response to potassium deficiency stress in tomato
}

Xin Liu ${ }^{1,2,3}$, Chunchang Tan ${ }^{1,2,3}$, Xin Cheng ${ }^{1,2,3}$, Xiaoming Zhao ${ }^{1}$, Tianlai $\mathrm{Li}^{1,2,3}$ and Jing Jiang ${ }^{1,2,3^{*}}$

\section{Correction to: BMC Plant Biol 20, 477 (2020) \\ https://doi.org/10.1186/s12870-020-02660-5}

In the original publication [1] there was an incorrect reference citation. In this correction article the incorrect and correct information are listed.

2. Hou XX, Cui J, Liu WW, Jiang N, Zhou XX, Qi HY, Meng J, Luan YS. LncRNA39026 enhances tomato resistance to Phytophthora infestans by decoying miR168a and inducing PR gene expression. Genet Res. 2020; 110(4):1943

Incorrect

- $\mathrm{K}^{+}$deficiency in soil is of great agricultural importance [2].

\section{Correct}

- $\mathrm{K}^{+}$deficiency in soil is of great agricultural importance.

\section{Author details}

${ }^{1}$ Horticulture Department, College of Horticulture, Shenyang Agricultural University, No. 120 Dongling Road, Shenhe District, Shenyang 110866, P. R. China. ${ }^{2}$ Key Laboratory of Protected Horticulture of Ministry of Education, No. 120 Dongling Road, Shenhe District, Shenyang 110866, P. R. China. ${ }^{3}$ Key Laboratory of Protected Horticulture of Liaoning Province, No. 120 Dongling

Road, Shenhe District, Shenyang 110866, P. R. China.

Published online: 08 February 2021

\section{References}

1. Liu X, Tan C, Cheng X, et al. miR168 targets Argonaute1A mediated miRNAs regulation pathways in response to potassium deficiency stress in tomato. BMC Plant Biol. 2020;20:477 https://doi.org/10.1186/s12870-020-02660-5.

The original article can be found online at https:/doi.org/10.1186/s12870020-02660-5.

* Correspondence: 116029050@qq.com

${ }^{1}$ Horticulture Department, College of Horticulture, Shenyang Agricultural University, No. 120 Dongling Road, Shenhe District, Shenyang 110866, P. R. China

${ }^{2}$ Key Laboratory of Protected Horticulture of Ministry of Education, No. 120 Dongling Road, Shenhe District, Shenyang 110866, P. R. China

Full list of author information is available at the end of the article

(c) The Author(s). 2021 Open Access This article is licensed under a Creative Commons Attribution 4.0 International License, which permits use, sharing, adaptation, distribution and reproduction in any medium or format, as long as you give appropriate credit to the original author(s) and the source, provide a link to the Creative Commons licence, and indicate if changes were made. The images or other third party material in this article are included in the article's Creative Commons licence, unless indicated otherwise in a credit line to the material. If material is not included in the article's Creative Commons licence and your intended use is not permitted by statutory regulation or exceeds the permitted use, you will need to obtain permission directly from the copyright holder. To view a copy of this licence, visit http://creativecommons.org/licenses/by/4.0/. The Creative Commons Public Domain Dedication waiver (http://creativecommons.org/publicdomain/zero/1.0/) applies to the data made available in this article, unless otherwise stated in a credit line to the data. 